\title{
Impacts of Financial Distress on Real and Accrual Earnings Management
}

\author{
Danella Rachel Muljono ${ }^{1}$, Kim Sung Suk. ${ }^{2}$ \\ Management Department, Business School, Pelita Harapan University \\ 1danellarachel@gmail.com, 22sungsuk.kim@uph.edu
}

\begin{abstract}
This research investigates the impact of financial distress on the magnitude of different earnings management approaches, namely real earnings management and accruals earnings management. This research utilizes a total of 2002 firm-year observations from 259 publicly-listed companies and 20 sub-industries in Indonesia from the year 2005 to 2014. Financial distress causes a significant increase of real earnings management and a significant decrease of accruals earnings management. It means that the healthier the company, the bigger the magnitude of real earnings management that is conducted through managing production costs and discretionary expenses. On the other hand, the lower the financial health of the company, the bigger the magnitude of accruals earnings management that is conducted through managing discretionary component of accruals.
\end{abstract}

Keywords: earnings management, real earnings management, accruals earnings management, financial distress

\section{INTRODUCTION}

This study observes earnings management behavior driven by financial condition of Indonesian publicly-listed companies over the year 2005-2014. An extended number of prior studies have analyzed the impact of financial distress on accruals earnings management (e.g. Charitou, Lambertides, \& Trigeorgis, 2007; Bisogno \& De Luca, 2015; Agrawal \& Chatterjee, 2015), however only a very limited number of studies have analyzed the impact of financial distress on real earnings management (e.g. Zang, 2012; Campa \& Camacho-Miñano, 2015). This study aims to provide a more comprehensive view on the overall impact of financial distress on the magnitude of real earnings management and accruals earnings management, both comprehending income-decreasing or incomeincreasing behaviors. We provide evidence that financial distress increases the magnitude of accruals earnings management but decreases the magnitude of real earnings management.

Within the context of Indonesia, the gradual adoption of International Financial Reporting Framework issued by International Accounting Standards Board has been proven by several researchers as inefficient in the reduction of earnings management practices (e.g. Anggraeni \& Fadilah, 2015). Other researchers have provided notable factors that are important in the reduction of earnings management practices aside from merely adoption of improved standards, such as strong investor protection and investor rights (Leuz, Nanda, \& Wysocki, 2003) or a country's legal and political system (Soderstrom \& Sun, 2007). One of the latest findings by Campa \& Camacho-Miñano (2015) reveals that a firm's financial condition contributes even more to earnings management practices than the institutional settings in which the firm operates in. Thus, it is interesting to study firm-specific 
conditions and their influence on the magnitude of earnings management practices, as it puts lights on a definite contributor of earnings management.

Real earnings management, according to Schipper (1989), is indicated by changes within the company's operations through either timing decisions or financing decisions aimed to direct earnings in a desired manner. On the other hand, accruals earnings management is direct changes on the income statement instead without changes within the company's operations (Yaping, 2005). Since the activity and consequences of real earnings management are harder to comprehend, decision-making process of users of financial statement are more severely impaired than in accruals earnings management (Kothari, Mizik, \& Roychowdhury, 2016). Previous researchers have found that due to higher levels of distress, companies conduct higher levels of income-decreasing accruals earnings management (Charitou et al., 2007; Agrawal \& Chatterjee, 2015), whereas other have found that higher levels of distress cause companies to conduct higher levels of income-increasing accruals earnings management instead (Bisogno \& De Luca, 2015). Nevertheless, these researchers have proven that financial distress impacts the level of accruals earnings management positively, despite the differing incentives to achieve target earnings. Thus, I hypothesize that the higher the level of distress, the higher the level of accruals earnings management conducted. On the other hand, the impact of financial distress on the magnitude of real earnings management is not as conclusive as on the magnitude of accruals earnings management, as the researches are much more limited than in accruals earnings management. Campa \& Camacho-Miñano (2015) finds that companies facing higher levels of distress conduct higher levels of income-increasing real earnings management, as companies are aggressively trying to avoid actual probable bankruptcy. Zang (2012) and Joosten (2012) find the opposite, in which companies facing higher levels of distress conduct lower levels of income-increasing real earnings management instead, as companies that are distressed do not have the capacity to deviate from optimal business operations. Due to similar sample characteristics with Zang (2012) and Joosten (2012), I hypothesize that the higher the level of distress, the lower the level of real earnings management conducted due to incapability and unwillingness to force a sub-optimal business operations that will result in damaging long-term consequences to stakeholders.

Through Fama \& MacBeth (1973) two-step procedure and after controlling for company performance, capital structure, size, growth opportunity, operating cash flows, market share, and cash cycle, this study finds that a company's financial condition is indeed a significant contributor towards not only the magnitude of accruals earnings management, but also the magnitude of accruals earnings management. Specifically, when companies are more financially well-off, they conduct higher levels of real earnings management than accruals earnings management, as their financial health and competitiveness in the industry enable them to deviate from optimal business operations. On the other hand, when companies are more financially distressed, they resort to higher levels of accruals earnings management instead in order to achieve the desired earnings target.

There are several purposes of this study that I aim to achieve. Firstly, this study is to put light on not only earnings management practices but also on specific contributors of earnings management practices in Indonesia, especially financial distress. Since financial distress is a broad concept, this research aims to break down the concept and help readers understand different aspects of financial distress. A better understanding of financial distress may help readers prevent harmful costs or conduct proper damage controls if companies happen to face distress. If its impacts are not being treated properly, financial 
distress can incur harmful costs for both the company and its stakeholders (Wruck, 1990). However, an early detection of financial distress can be an appropriate starting point of a better management and operations within the company (Wruck 1990; Whitaker, 1999).

Secondly, this research is to provide insights on the relationship between a company's financial condition and the magnitude of different earnings management approaches undertaken, especially real earnings management, since the topic is under-researched although it has a more severe long-term consequences than accruals earnings management (Zang, 2012; Campa \& Camacho-Miñano, 2015). This study extends previous researches by analyzing the impact of severity of financial distress on the overall magnitude of real earnings management and accruals earnings management, encompassing both incomeincreasing and income-decreasing behaviors. Comparing the impact of financial distress on the magnitude of both approaches should help readers to understand the conclusive effect of distress on managerial behaviors. If a company is not in severe distress, it does not mean that the company is completely absent from potentially damaging earnings management practices, because the company may switch from one earnings management practice to another.

Thirdly, this research is to aid in the decision-making process of the readers when dealing with contracts, compensations, investments, or any other activities that are based on financial reports. Three main users of financial reports, 1) investors, 2) lenders, and 3) other creditors may be able to understand and detect the presence of specific earnings management practice when the company experiences a specific financial condition and at the same time may help companies analyze the source of distress and conduct needed actions, before the practices go beyond "acceptable" boundaries and inflict further consequences for the firm and its stakeholders. Policy makers and regulatory authorities may conduct further improvements of accounting and financial regulations regarding the procedures in dealing with probable bankruptcy and in the extent of acceptable earnings management practices, especially of real earnings management.

\section{LITERATURE REVIEW}

Real versus Accrual Earnings Management. Earnings, also known as the "bottom line" in financial information, are believed to be the most important information in financial statements to all users of financial information such as to analysts, investors, creditors, researchers, and regulators (Tabassum, Kaleem, \& Nazir, 2015). Interviews and surveys to CFO conducted by Graham, Harvey, \& Rajgopal (2005) reveal that financial officers view earnings, especially EPS, as the most important indicator of company's performance for external stakeholders. Moreover, earnings are frequently used as a measure of manager's performance and benchmark of manager's compensations (Cohen, Dey, \& Lys, 2007). Due to the importance and wide uses of earnings, managers may try to manage earnings in order to achieve the desired goal - a practice that is known as earnings management.

According to a joint framework of GAAP and IFRS known as Conceptual Framework for Financial Reporting 2010, "The objective of general purpose of financial reporting is to provide financial information about the reporting entity that is useful to existing potential investors, lenders, and other creditors in making decisions about providing resources to the entity." (International Accounting Standards Board, 2010 p.9). According to the joint framework, financial reporting is to provide information which is useful, in a sense that the 
information is relevant and faithfully represented. However, the discretion under financial reporting may give rise to earnings management that misrepresents rather than signals true information, which ultimately impairs decision-making process of three main users of financial reports: 1) investors, 2) lenders, and 3) other creditors.

Schipper (1989) is one of the earliest researches to mention real earnings management in paper. She defines earnings management and real earnings management as: "a purposeful intervention in the external financial reporting process, with the intention of obtaining some private gain...[a] minor extension of this definition would encompass "real" earnings management, accomplished by timing investment or financing decision to alter reported earnings or some subset of it." (Schipper, 1989, p.92) According to the stated definition, real earnings management changes the operations of the business either through timing decisions or financial decisions (such as changing the timing of sales, delaying needed investments, and selling fixed assets in order to alter current earnings) (Gunny, 2005). Dechow \& Skinner (2000) suggest that real cash flow choices can be conservative or aggressive. Conservative choices include income-decreasing practices such as delaying sales or accelerating R\&D or advertising expenditures, whereas aggressive choices include income-increasing practices such as accelerating sales or postponing R\&D or advertising expenditures (Dechow \& Skinner, 2000). Real earnings management practices are to result in sub-optimal operational practices, thus the practices may negatively impact the company's future value (Roychowdhury, 2006). For instance, previous studies conducted by Tabassum et al., (2015) and Razzaque, Ali, \& Mather (2015) prove that companies' future financial performances which conducted real earnings management in previous years are much worse compared to those that do not conduct real earnings management. Moreover, since the practice and consequences of real earnings management are much harder to detect compared to accruals earnings management, the decision-making process of users of financial reports are more impaired than in accruals earnings management (Kothari et al., 2016).

While real earnings management alters the underlying operations of the company, accruals earnings management causes direct changes on income statement without changes in the underlying operations of the company (Yaping, 2005). Accruals earnings management may be done through changes in accounting methods, such as inventory costing method and depreciation method or changes in accounting estimates, such as provision, allowances, and write-offs (Zang, 2012). These changes are possible due to revenue-recognition principle under accounting standards, as not all business operations can be reflected through the companies' cash level. While cash flows component is fixed, accruals component is sensitive to subjectivity. Therefore, due to the high degree of subjectivity imposed, the earnings (or net income) component in an income statement may not signal the underlying operations of the company and thus may not be relevant and reliable. However, since accruals naturally reverse overtime, companies that conduct accruals earnings management must recognize actual amounts that were previously managed overtime, causing them to affect future accounting numbers and lose flexibility in future accounting choices and estimates (Allen, Larson, \& Sloan, 2013). This phenomenon induces managers that run out of ways to manage earnings to conduct earnings fraud, such as writing down fictitious accounts (Dechow, Sloan, \& Sweeney, 1996). Accruals earnings management are constrained due to presence of qualified audit opinions (Charitou et al., 2007), heighted scrutiny especially after SOX period (Lasdi, 2013), and strong investor protection within the country (Enomoto, Kimura, \& Yamaguchi, 2015). 
Even if firms experience significant negative long-term consequences with real earnings management, the practice is still preferred over accruals earnings management. According to surveys conducted by Graham et al., (2005), 80\% of financial executives would decrease discretionary expenditures on R\&D and advertising and maintenance and $55.3 \%$ would delay investments to meet earnings target despite negative future consequences on firm value. On the contrary, much less executives would conduct accruals earnings management, as only less than $30 \%$ would draw down reserves and postpone accounting charges and only less than $10 \%$ would alter accounting assumptions (such as allowances and pensions) (Graham et al., 2005). Since earnings level has been widely used as an important measure of company performance, authorities seem to be willing to sacrifice cash flows and optimal business operations to enhance earnings more than impose changes in accounting numbers or methods, in which changes in accounting numbers are relatively easier to detect and subject to more scrutiny.

Earnings Management and Financial Distress. Previous studies have observed that companies under stress tend to manage earnings for varying reasons. Bisogno \& De Luca (2015) investigate whether financial distress affects the level of accruals earnings management in 200 firm-years observations of Italian small and private companies. They find that managers in small firms tend to conduct higher levels of income-increasing accruals earnings management, not to meet analysts' or investors' expectations like big and public firms do, but rather to maintain bank loans. Other reasons for income-increasing accruals earnings management during distress is to avoid debt covenant violations, avoid probable bankruptcy, avoid turnover, or increase management compensations (Charitou et al., 2007). The incentive to increase income in order to increase management compensations is further emphasized by Beneish (2001). Beneish (2001) reveals that income-increasing earnings management is more prevalent than income-decreasing earnings management with the intention to hide poor performance, thus enabling managers to sell managers' equity contingent wealth at higher prices. Other researchers have found the opposite, in which distress induces income-decreasing earnings management instead. Research conducted by Charitou et al. (2007) shows that new managers within the company manage accruals earnings downwards prior to bankruptcy by earnings bath due to two main reasons. First, new managers aim to blame prior managers for the poor management. Second, new managers experience pressure from auditors to engage in conservative earnings behavior, because during high levels of distress there is higher scrutiny from auditors. Agrawal \& Chatterjee (2015) study the relationship between accruals earnings management and 150 financially distressed firms from 2009 to 2014 in India. The study shows that early distressed firms manage accrual earnings upwards, while severely distressed firms manage accrual earnings downwards. They suggest that managers' behavior depends on the financial situation; for instance, when the distress level is high, firms try to be more conservative in its earnings with the aim to obtain better financing terms with creditors. Nevertheless, all of these previous researches suggest a significant impact of distress towards the magnitude of accruals earnings management.

On the other side, only few other researchers have focused on the impact of financial distress on real earnings management. For instance, Campa \& Camacho-Miñano (2015) investigate how financial distress impacts to the trade-off between real earnings manipulation and accruals earnings manipulation prior to actual bankruptcy filing. They suggest that small and medium private enterprises prior to bankruptcy conduct more 
extensive upward real earnings management and less upward accruals earnings management at higher levels of financial distress, because at lower levels of distress managers have weaker incentives to manage earnings forcefully. Zang (2012), who studies earnings management behavior on public companies, finds the opposite; she shows that healthier companies conduct higher levels of real earnings management rather than accruals earnings management because healthy companies have more flexibility to deviate from optimal business operations due to their competitive advantage in the industry. Zang's (2012) research is further supported by Joosten (2012), in which accruals earnings management is more prevalent in companies that experience distress and higher industry competition. As far as the researcher's findings, researches in the Indonesian context regarding both earnings management approaches, especially how they are influenced by financial situation have been very limited. Previous researches in the Indonesian context tend to focus only on specific type of industry and on short span of time.

Hypothesis Development. Financial distress may cause pressure for the company, because distress may inflict direct costs (such as legal, administrative, and advisory fees) and indirect costs (such as loss of flexibility, reduction of demand, increase of core expenses, increase of cost of capital, and loss of valuable time to the company) (Altman, 1984); even though the presence of financial distress may actually be the beginning of a more efficient company (Wruck, 1990). As discussed previously, previous literatures have found that due to pressure, managers are encouraged to conduct earnings management for various reasons such as to avoid management turnover (Charitou et al., 2007), avoid debt covenant violations (Kim, Lei, \& Pevzner, 2011) maintain bank loans (Bisogno \& De Luca, 2015), or avoid probable bankruptcy (Campa \& Camacho-Miñano, 2015).

Intuitively, when a company is financially distressed, it may need to inflate its earnings to avoid probable bankruptcy. However, the specific impact of financial distress on real earnings management has conflicting views. For instance, several researchers have found that during higher levels of distress, companies conduct higher levels of incomeincreasing real earnings management. A research by Kim et al. (2011) depicts that managers conduct higher levels of income-increasing real earnings management when net worth covenant slack is tighter, especially when the borrowers experience higher bankruptcy risk. This view is consistent with Campa \& Camacho-Miñano (2015), whose findings reveal that prior to bankruptcy, private companies conduct higher levels of income-increasing real earnings management as they are aggressively trying to avoid probable bankruptcy. However, other researchers find the opposite. For instance, Zang (2012) reveals that at initial stages of distress, companies conduct real earnings management more prevalently than accruals earnings management, because the companies have the capacity to deviate from optimal business decisions. Since real earnings management is risky due to its longterm economic consequences, companies that are under severe distress are going to shift from real earnings management and conduct accruals earnings management more prevalently instead to meet the desired targets. These views are supported by Joosten (2012), in which European companies conduct real earnings management to reach earnings targets when distress is low instead, because the companies' capacities enable them to mitigate the negative economic consequences of real earnings management. Nagar \& Sen (2016) find that during initial stages of distress, companies engage in real earnings management through reduction in discretionary expenses; at higher stages of distress, companies engage in higher levels of accruals earnings management. Campa \& Camacho- 
Miñano (2015) explain that their findings are different from Zang's (2012) because of difference in sample characteristics and thus difference in intentions. Campa \& CamachoMiñano (2015) use samples of small and medium private firms that have actually gone bankrupt. Since this research utilizes sample of publicly listed companies that have not actually went bankrupt, the hypothesis is similar to that of Zang (2012) and Joosten (2012). Measured through Z"-Score ratio, companies that are at lower levels of distress conduct higher magnitude of real earnings management to reach earnings target. Therefore, $\mathrm{H}_{1}$ is as follows:

H1: The higher (lower) the level of financial distress, the lower (higher) the magnitude of real earnings management.

Bisogno \& De Luca (2015) find that financial distress has a significant positive relationship with income-increasing accruals earnings management, with the main intention to conceal true performance and maintain debt financing from banks. On the contrary, Charitou et al. (2007) find that higher level of distress causes firms to conduct income-decreasing accruals earnings management instead, as managers are pressured to be more conservative by auditors. Moreover, with more conservative earnings, new managers are able to blame poor performance on prior managers and attribute seemingly better future performance on themselves. Either way, distress causes firms to manage accruals earnings more extensively. Zang (2012), Joosten (2012), and Nagar \& Sen (2016) directly compare the behavior of financially distressed firm on accruals earnings management and real earnings management at the same time. All of their findings are consistent to many other researchers, which indicate that financially distressed firms resort to higher levels of accruals earnings management (Charitou et al., 2007; Bisogno \& De Luca, 2015; Nagar \& Sen, 2016).

Since this research is focused on comparing the impact of financial distress on real earnings management and accruals earnings management at the same time and not necessarily focused on income-decreasing or income-increasing behavior during distress, absolute value of discretionary accruals is used to indicate the presence of accruals-earnings management as a whole. Whether a company conducts income-increasing accruals earnings management or income-decreasing accruals earnings management, this research aims to observe whether the severity of financial condition has an impact on total amount of accruals managed. Consistent with all of these researches, it is hypothesized that the higher the level of financial distress, the bigger the magnitude of accruals earnings management. More specifically, companies switch from real earnings management to accruals earnings management, as companies' ability to run real earnings management is impaired when distress level gets higher (Zang, 2012; Joosten, 2012). Therefore, $\mathrm{H}_{2}$ is as follows:

$\mathbf{H}_{2}$ : The higher (lower) the level of financial distress, the higher (lower) the magnitude of accruals earnings management.

\section{METHOD}

Data. We use all Indonesian companies listed in Bursa Efek Indonesia from 2005 to 2014, with an additional lag period of two years as a requirement for the corresponding variables. Therefore, an observation of company A at the year 2005 consists of data from the year 2002. A maximum of ten years of data is utilized to allow for a larger data set that should help increase reliability and relevancy of findings. Financial companies and industry-year observation that constitutes of less than six firm-year observations is also dropped from the 
sample to derive reliable values of abnormalities (Subramanyam, 1996). Lastly, all of the data is winsorized at top and bottom one percent to reduce noise due to extreme observations. After exclusion of observations, the data set used in this research consists of 20 sub-industries, 259 companies, and 2002 firm-year observations for at most ten years period of time. The data set is regressed through Fama \& MacBeth (1973) two-step procedure adjusted for autocorrelation treatment through Newey-West (1987) estimator, following Roychowdhury (2006).

Empirical Model for Real Earnings Management. The model that is used to measure the extent of real earnings management are the combined models of abnormal production costs and abnormal discretionary expenses that were developed by Roychowdhury (2006). Roychowdhury (2006) concludes that earnings management is deviations from normal operational practices to direct earnings in the desired way. He measures the deviations through abnormalities in the level of cash flows from operation, production costs, and discretionary expenses. However, Roychowdhury's (2006) paper does not discuss further on details regarding income-decreasing real earnings management, since his research is focused on income-increasing behavior. Francis (2015) provides further research on income-decreasing real earnings management, stating that negative abnormal production costs reflect increase in selling prices, decrease in promotions, or tighter credit terms; whereas negative abnormal discretionary expenses reflect increases in discretionary spendings. Consistent with Zang (2012), this study is going to utilize the sum of abnormal production costs and abnormal discretionary expenses due to the ambiguous net effect of real practices on the abnormal level of cash flows from operations. Since this study aims to capture the overall magnitude of earnings management approaches, both income-increasing and income-decreasing, abnormal production costs and abnormal discretionary expenses are transformed into absolute values before summing them up into one comprehensive measure of real earnings management. Roychowdhury's (2006) models utilized in this research are as follows:

$$
\begin{aligned}
& P R O D_{i t} / A_{i t-1}=\alpha+\beta_{1}\left[1 / A_{i t-1}\right]+\beta_{2}\left[S_{i t} / A_{i t-1}\right]+\beta_{3}\left[\Delta S_{i t} / A_{i t-1}\right]+\beta_{4}\left[\Delta S_{i t-1} / A_{i t-1}\right]+\varepsilon_{i t} \quad-----(1) \\
& \operatorname{DISEXP}{ }_{i t} / A_{i t-1}=\alpha+\beta_{1}\left[1 / A_{i t-1}\right]+\beta_{2}\left[S_{i t-1} / A_{i t-1}\right]+\varepsilon_{i t}
\end{aligned}
$$

$\mathrm{PROD}_{\text {it }}=\mathrm{COGS}_{\mathrm{it}}+\Delta \mathrm{INV}_{\text {it }}$ or production costs during period $\mathrm{t}, \mathrm{DISEXP}_{\mathrm{it}}=$ discretionary expenses during period $t, A_{i t}=$ total assets at the end of period $t, A_{i t-1}=$ lagged total assets, $S_{i t}=$ total sales during period $t, S_{i t-1}=$ lagged sales, $\Delta S_{i t}=$ change in sales computed as $\mathrm{S}_{\mathrm{it}}-\mathrm{S}_{\mathrm{it}-1}, \Delta \mathrm{S}_{\mathrm{it}-1}=$ change in sales computed as $\mathrm{S}_{\mathrm{it}-1}-\mathrm{S}_{\mathrm{it}-2}$, $\varepsilon_{\mathrm{it}}=$ error term or the abnormal values

Then, the empirical model to test $\mathrm{H}_{1}$ is as follows:

$$
\begin{aligned}
R M_{i, t}=\alpha_{i, t}+\beta_{1} Z_{i . t}+ & \beta_{2} R O A_{i, t}+\beta_{3} L E V_{i, t}+\beta_{4} S I Z E_{i, t}+\beta_{5} M T B_{i, t}+\beta_{6} C F O_{i, t}+\beta_{7} M S_{i, t}+\varepsilon_{i, t} \\
\mathrm{RM}_{\mathrm{i}, \mathrm{t}}= & \text { Real earnings management, as measured by the absolute } \\
& \text { value of abnormal production costs and abnormal } \\
& \text { discretionary expenses from equation (1) and (2) } \\
= & \text { Financial distress, as measured by Altman } \mathrm{Z} \text { '-Score } \\
\mathrm{Z}_{\mathrm{i}, \mathrm{t}} & \text { Return on assets, as measured by net income scaled by } \\
\mathrm{ROA}_{\mathrm{i}, \mathrm{t}} & \text { lagged total assets }
\end{aligned}
$$




$\begin{aligned} \mathrm{LEV}_{\mathrm{i}, \mathrm{t}}= & \text { Leverage ratio, as measured by total debt scaled by total } \\ & \text { assets } \\ \mathrm{SIZE}_{\mathrm{i}, \mathrm{t}}= & \text { Size, as measured by natural logarithm of total assets } \\ \mathrm{MTB}_{\mathrm{i}, \mathrm{t}}= & \text { Market-to-book ratio, as measured by market value of equity } \\ & \text { scaled by book value of equity } \\ \mathrm{CFO}_{\mathrm{i}, \mathrm{t}}= & \text { Operating cash flows, as measured by operating cash flows } \\ & \text { scaled by total assets } \\ \mathrm{MS}_{\mathrm{i}, \mathrm{t}}= & \text { Market share, as measured by company sales scaled by } \\ & \text { industry sales }\end{aligned}$

Financial distress, being the tested independent variable of this study, is going to be based on Altman Z"-Score model developed by Altman, Hartzell, Heine, \& Peck (1995), which is suited to developing countries. The model is as follows:

$$
Z^{\prime \prime}=3.25+6.56 X_{1}+3.26 X_{2}+6.72 X_{3}+1.05 X_{4}
$$

$\mathrm{Z}$ " = overall index, $\mathrm{X}_{1}=$ working capital/total assets, $\mathrm{X}_{2}=$ retained earnings/total assets, $\mathrm{X}_{3}$ $=$ earnings before interest and taxes/total assets, $\mathrm{X}_{4}=$ book value equity/book value of total liabilities

Other independent variables included are control variables such as return on assets, leverage ratio, size, market-to-book ratio, operating cash flows, market share, and cash cycle. Return on assets is added to control for extreme performance, as suggested by Kothari, Leone, \& Wasley (2005). As for the impact of leverage ratio towards accruals earnings management, Januarsi, Badina, \& Febrianti (2014) and Bisogno \& De Luca (2015) argue that leverage causes higher levels of accruals earnings management, because highlyleveraged companies need to showcase good financial performance in order to obtain even more loans. Scott (2000) in Nikoomaram, Banimahd, \& Shokri (2012) suggests that firms with higher debt ratio are more likely to engage in earnings management in order to avoid debt covenant violations and the costs associated with them. However, others have argued the opposite, explaining that highly leveraged companies are constrained to conduct higher levels of earnings management, because their financial condition attracts more scrutiny from stakeholders (Iturriaga \& Hoffmann, 2005; Nikoomaram et al., 2012). Zamri, Rahman, \& Isa (2013) and Januarsi et al. (2014) argue that leverage with real earnings management has a negative relationship, because their financial position constrains them from conducting earnings management practices. Another control variable, size, is added to control for differences in assets size. Zamri et al. (2013) find that large firms tend to conduct real earnings management less because large firms already get to enjoy economies of scale and economies of scope, therefore they refrain from real earnings management activities. On the other hand, Bisogno \& De Luca (2015) argue that smaller firms engage in higher accruals earnings management because smaller firms do not need to comply to strict rules and disclosure requirements. Growth firms (firms with higher market-to-book ratio) have a positive significant relationship with earnings management, because growth firms experience the pressure to meet earnings targets (Roychowdhury, 2006). Consistent with Campa \& Camacho-Miñano (2015), cash flows from operations is added in order to control for extreme performance. Their results indicate that the lower the cash flows from operations, the higher the level of earnings management and accruals earnings management. Zang (2012) finds that market share plays an important role in earnings management, as a firm that has larger market share has more capacity to deviate from optimal business 
operations, thus enabling it to conduct real earnings management at higher levels. Therefore, market share control is added to control variations in real earnings management. This variable is also used by Badertscher (2011) and Joosten (2012) to control for real earnings management.

Empirical Model for Accrual Earnings Management. The measure of accruals earnings management is going to be based on abnormal discretionary accruals derived from the Modified Jones model by Dechow, Sloan, \& Sweeney (1995). This research conducts crosssectional regressions on the Modified Jones model by Dechow et al. (1995). Bartov, Gul, \& Tsui (2001) conclude that cross-sectional Jones models are better than the time-series models, because in the cross-sectional models, 1) the number of observations is larger and thus can yield more precise estimates, 2) the sample is less exposed to the survivorship bias, and 3 ) the model allows the inclusion of short-lived samples. Therefore, the parameters a1, a2, and a3 are industry-year specific rather than firm-year specific. The cross-sectional accruals model has also been done by many other researchers (Sloan, 1996; Tendeloo \& Ann, 2005; Roychowdhury, 2006; Cohen et al., 2007; Yang, Hsu, \& Yan, 2015). The following Modified Jones Model by Dechow et al. (1995) is used by regressing every industry every year to derive the abnormal values of discretionary accruals:

$$
N D A_{i t}=a_{1}\left(1 / A_{i t-1}\right)+a_{2}\left(\triangle R E V_{i t} / A_{i t-1}-\Delta R E C_{i t} / A_{i t-1}\right)+a_{3}\left(P P E_{i t} / A_{i t-1}\right)
$$

$\mathrm{TA}_{\mathrm{it}}=$ total accruals for period $\mathrm{t}$ as measured by net income before extraordinary items deducted by operating cash flows, $\mathrm{NDA}_{i t}=$ non- discretionary accruals for period $\mathrm{t}, \mathrm{DA}_{\mathrm{it}}$ $=$ non-discretionary accruals for period $\mathrm{t}, \mathrm{A}_{\mathrm{it}-1}=$ lagged total assets, $\mathrm{a}_{1}, \mathrm{a}_{2}, \mathrm{a}_{3}=$ parameters obtained from $\alpha_{3}, \alpha_{2}, \alpha_{3}, \Delta \mathrm{REV}_{\mathrm{it}}=$ change in revenue computed as $\mathrm{REV}_{\mathrm{it}}-\mathrm{REV}_{\mathrm{it}-1}, \Delta \mathrm{REC}_{\mathrm{it}}=$ change in receivables computed as $\mathrm{REC}_{\mathrm{it}}-\mathrm{REC}_{\mathrm{it}-1}, \mathrm{PPE}_{\mathrm{it}}=$ plant, property, and equipment during period $\mathrm{t}$

The empirical model to test $\mathrm{H}_{2}$ is as follows:

$$
A M_{i, t}=\alpha_{i, t}+\beta_{1} Z_{i . t}+\beta_{2} R O A_{i, t}+\beta_{3} L E V_{i, t}+\beta_{4} S I Z E_{i, t}+\beta_{5} M T B_{i, t}+\beta_{6} C F O_{i, t}+\beta_{7} C Y C L E_{i, t}+\varepsilon_{i, t}
$$

$\begin{array}{ll}\mathrm{AM}_{\mathrm{i}, \mathrm{t}}= & \text { Accruals earnings management, as measured by the absolute } \\ & \text { value of abnormal discretionary accruals from equation (4) } \\ \mathrm{Z}_{\mathrm{i}, \mathrm{t}} & \text { Financial distress, as measured by Altman } \mathrm{Z} \text { '-Score } \\ \mathrm{ROA}_{\mathrm{i}, \mathrm{t}}= & \text { Return on assets, as measured by net income scaled by } \\ & \text { lagged total assets } \\ \mathrm{LEV}_{\mathrm{i}, \mathrm{t}}= & \text { Leverage ratio, as measured by total debt scaled by total } \\ & \text { assets } \\ \mathrm{SIZE}_{\mathrm{i}, \mathrm{t}}= & \text { Size, as measured by natural logarithm of total assets } \\ \mathrm{MTB}_{\mathrm{i}, \mathrm{t}}= & \text { Market-to-book ratio, as measured by market value of equity } \\ & \text { scaled by book value of equity }\end{array}$




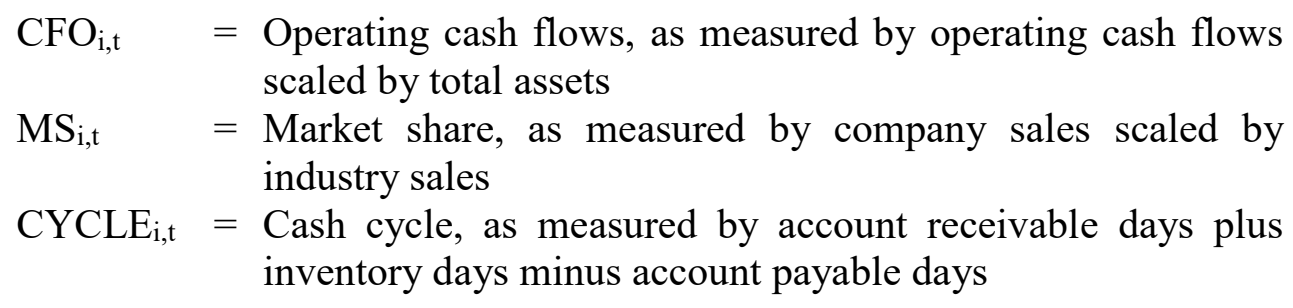

The independent and control variables in the empirical model for accruals earnings management are the same with the ones in the empirical model for real earnings management, except that market share is replaced with cash cycle. Cash cycle is added because cash cycle has been proven to significantly influence a manager's flexibility to manage accruals (Zang, 2012).

\section{EMPIRICAL RESULTS}

Descriptive Statistics. Descriptive statistics in this research is based on full sample, distressed and non-distressed samples. The distinction of the distressed and the nondistressed are based on their respective Z"-Scores dummies; companies with Z"-Score value equal to or less than 3.75 is regarded as distressed (1) and companies with Z"-Score value equal to or more less than 5.65 is regarded as non-distressed (0). The sample that is classified as distressed amounts to 343 firm-year observations, whereas the sample that is classified as non-distressed amounts to 1182 firm-year observations. In total, the full sample amounts to 2002 firm-year observations.

Table 1. Descriptive Statics (Full Sample)

\begin{tabular}{lcccc}
\hline Variable & Mean & Std. Dev. & Min. & Max. \\
\hline RM & 3.6052 & 20.1409 & 0.0043 & 170.8012 \\
AM & 0.0720 & 0.0851 & 0.0004 & 0.5064 \\
Z & 6.4944 & 5.8372 & -20.7125 & 26.5474 \\
ROA & 0.0499 & 0.1088 & -0.3498 & 0.4806 \\
LEV & 0.2455 & 0.2349 & 0.0000 & 1.4137 \\
SIZE & 6.0700 & 0.7196 & 4.2505 & 7.7632 \\
MTB & 1.8175 & 2.5134 & -2.3447 & 16.2861 \\
CFO & 0.0462 & 0.0981 & -0.2516 & 0.3671 \\
MS & 0.0738 & 0.10845 & 0.0002 & 0.5269 \\
CYCLE & 225.5911 & 507.9644 & -194.9308 & 3096.1300 \\
\hline
\end{tabular}

$\mathrm{RM}$ is the sum of absolute value of abnormal production costs and abnormal discretionary expenses; AM is the absolute value of abnormal discretionary accruals; Z" is Altman Z"-Score; ROA is net income scaled by lagged total assets; LEV is total debt scaled by total assets; SIZE is natural logarithm of total assets; MTB is market value of equity scaled by book value of equity; CFO is operating cash flows scaled by total assets, MS is company sales scaled by industry sales, CYCLE is account receivable days plus inventory days minus account payable days

Based on the full sample descriptive statistics, Indonesian companies have a mean Z"Score of 6.4944, indicating that they are in a financially sound condition with an average Standard and Poors rating of $\mathrm{BBB}$ or $\mathrm{BBB}+$. Cash cycle has the highest standard deviation (507.9644), ranging from an extreme negative value of -194.9308 days to an extreme 
positive value of 3096.13 days. Companies with negative cash cycle are mostly from retail trade industry, where cash received tend to be much faster than cash paid; whereas companies with extreme positive cash cycle are mostly from property and real estate industry, where days in inventory tend to be much longer than other industries.

The different group descriptive statistics between the distressed and the non-distressed in table 4.2 provide more informative insights on companies' characteristics based on their financial condition. Sum of abnormal production costs and abnormal discretionary expenses is higher for non-distressed sample than distressed sample; showing the fact that nondistressed sample is able to conduct higher levels of real earning management, even though mean difference isn't significant. Abnormal total accruals is higher for distressed sample (0.0846) than for non-distressed sample (0.0691), meaning that distressed sample produces higher value of abnormal accruals or manages more accruals relative to the non-distressed sample. Z"-Score is much lower for distressed sample (-1.4174) than that of non-distressed sample (9.4643), which is as expected. It is also observed that the distressed sample suffers from lower returns on assets (-0.0419) than non-distressed sample (0.0849) and lower cash flows from operations scaled by total assets ( 0.0162 and 0.0619 respectively), which are as expected. It is also worth noting that distressed sample tend to be less competitive within the industry, with mean market share of 0.0543 compared to non-distressed sample mean market share of $(0.0728)$ Moreover, the distressed sample is also much more leveraged than non-distressed sample ( 0.4483 and 0.1570 respectively).

Table 2. Mean Difference between Distressed and Non-Distressed Firm

\begin{tabular}{|c|c|c|c|c|c|}
\hline & \multicolumn{2}{|c|}{ Distressed Sample } & \multicolumn{2}{|c|}{ Non-Distressed Sample } & \\
\hline & Mean & Std. Dev. & Mean & Std. Dev. & \\
\hline Variable & & & & & $\begin{array}{c}\text { Mean Difference } \\
(t \text {-stats })\end{array}$ \\
\hline $\mathrm{RM}$ & 3.1412 & 19.3393 & 3.9914 & 21.0179 & $\begin{array}{c}-0.8502 \\
(-0.6712)\end{array}$ \\
\hline $\mathrm{AM}$ & 0.0846 & 0.1065 & 0.0691 & 0.0799 & $\begin{array}{c}0.0155^{* * *} \\
(2.9207)\end{array}$ \\
\hline Z & -1.4174 & 6.4514 & 9.4643 & 4.1755 & $\begin{array}{c}-10.8816^{* * *} \\
(-37.1037)\end{array}$ \\
\hline $\mathrm{ROA}$ & -0.0419 & 0.1350 & 0.0849 & 0.0971 & $\begin{array}{l}-0.1269 * * * \\
(-19.3775)\end{array}$ \\
\hline LEV & 0.4483 & 0.3578 & 0.1570 & 0.1449 & $\begin{array}{c}0.2913 * * * \\
(22.3791)\end{array}$ \\
\hline SIZE & 5.7119 & 0.8116 & 6.1276 & 0.6729 & $\begin{array}{c}-0.4157 * * * \\
(-9.5944)\end{array}$ \\
\hline MTB & 1.7891 & 3.6247 & 1.8579 & 2.0644 & $\begin{array}{l}-0.06877 \\
(-0.4483)\end{array}$ \\
\hline $\mathrm{CFO}$ & 0.0162 & 0.0959 & 0.0619 & 0.0998 & $\begin{array}{c}-0.0456 * * * \\
(-7.5219)\end{array}$ \\
\hline MS & 0.0543 & 0.0926 & 0.0728 & 0.1064 & $\begin{array}{c}-0.0185 * * * \\
(-2.9075)\end{array}$ \\
\hline CYCLE & 74.9004 & 270.2283 & 292.5098 & 573.9795 & $\begin{array}{c}-217.6094 * * * \\
(-6.8048)\end{array}$ \\
\hline
\end{tabular}


*Significant at $10 \%$ level; **Significant at 5\% level; ***Significant at $1 \%$ level $\mathrm{RM}$ is the sum of absolute value of abnormal production costs and abnormal discretionary expenses; AM is the absolute value of abnormal discretionary accruals; $Z$ is Altman Z"-Score; ROA is net income scaled by lagged total assets; LEV is total debt scaled by total assets; SIZE is natural logarithm of total assets; MTB is market value of equity scaled by book value of equity; CFO is operating cash flows scaled by total assets, MS is company sales scaled by industry sales, CYCLE is account receivable days plus inventory days minus account payable days

Effects of Financial Distress on Real / Accrual Earnings Management. Table 4.3 presents Fama \& MacBeth (1973) final regression results, along with final coefficient values and their respective significant level. Error treatments using Newey-West (1987) estimator are applied simultaneously to the procedure.

Table 3. Fama \& MacBeth (1973) regression final results

\begin{tabular}{lcc}
\hline & RM & AM \\
\hline Intercept & $19.18232^{* * *}$ & $0.1007041^{* * *}$ \\
Z & $(6.21)$ & $(8.87)$ \\
& $0.0906262^{*}$ & $-0.0006191^{*}$ \\
ROA & $(1.86)$ & $(-2.03)$ \\
& 5.184259 & 0.0330965 \\
LEV & $(0.91)$ & $(1.79)$ \\
& -0.6879285 & -0.003387 \\
SIZE & $(-0.71)$ & $(-0.57)$ \\
& $-3.499871^{* * *}$ & $-0.0095217^{* * *}$ \\
MTB & $(-7.38)$ & $(-5.12)$ \\
& 0.0870897 & $0.0021768^{* *}$ \\
CFO & $(1.36)$ & $(2.47)$ \\
& $-4.739799^{* *}$ & $-0.0481921^{* * *}$ \\
MS / CYCLE & $(-2.35)$ & $(-5.42)$ \\
& $16.43022^{* * *}$ & $0.0000112^{* * *}$ \\
Industry dummies & $(7.12)$ & $(3.52)$ \\
F-stats & Yes & Yes \\
Average R & $7.40^{* * *}$ & $11.51^{* * *}$ \\
\hline
\end{tabular}

*Significant at $10 \%$ level; **Significant at $5 \%$ level; ***Significant at $1 \%$ level

Each column presents Fama \& MacBeth (1973) regression result for each dependent variable listed on the first row. T-statistics, reported in parenthesis, are calculated using standard errors corrected for autocorrelation and heteroscedasticity using the Newey-West (1987) estimator procedure.

RM is the sum of absolute value of abnormal production costs and abnormal discretionary expenses; AM is the absolute value of abnormal discretionary accruals; Z is Altman Z"-Score; ROA is net income scaled by lagged total assets; LEV is total debt scaled by total assets; SIZE is natural logarithm of total assets; MTB is market value of equity scaled by book value of equity; CFO is operating cash flows scaled by total assets, MS is company sales scaled by industry sales, CYCLE is account receivable days plus inventory days minus account payable 
Through Fama \& MacBeth (1973) two-step procedure, both of the null hypotheses are rejected. Therefore, consistent with the expected results, healthier companies significantly conduct higher magnitude of real earnings management and lower levels of accruals earnings management and vice versa. Consistent with Zang (2012) and Joosten (2012), healthier companies conduct higher magnitudes of real earnings management because healthier financial condition enables them to deviate from optimal business operations. Joosten (2012) further suggests that real earnings management during relatively healthier conditions is done to meet short-term targets. However, companies switch to accruals earnings management when distress is relatively higher because they have lost their financial competitive advantages within the market, thus they are discouraged to deviate from their most optimal business operations.

As for the control variables, LEV shows negative signs for both practices. Iturriaga \& Hoffmann (2005) suggest that high leverage ratio within a company restricts the flexibility for manager to manage earnings because it brings more monitoring. However, the values are insignificant. SIZE shows significant negative signs at one percent level for both practices. The coefficient sign for the impact of SIZE on real earnings management is aligned with research by Zamri et al. (2013). Zamri et al. (2013) state that bigger firms have lesser incentives to manage earnings upwards, because they are already benefited from economies of scale and economies of scope. On the other hand, the coefficient sign for the impact of SIZE on accruals earnings management is aligned with research by Bisogno \& De Luca (2015). Bisogno \& De Luca (2015) state that smaller firms enjoy more flexibility to manage accruals because they are not under as much pressure as larger firms to disclose information and they take advantage of the higher levels of information asymmetry. MTB shows positive signs for both earnings management practices, which are as expected. The sign shows a significant relationship with accruals earnings management, implying that highgrowth firms are pressured to meet their desired earnings targets and thus conduct higher levels of earnings management (Roychowdhury, 2006). Both coefficient signs on CFO are negative, which are consistent with Campa \& Camacho-Miñano (2015). Therefore, when companies have low levels of operating cash flows, they try to manage their operations and the accrual component of earnings in order to generate the desired level of earnings. The impact of MS on real earnings management is significantly positive, which is robust that companies with larger market share have more capacity to deviate from optimal business operations due to their competitive advantages (Zang, 2012). On the other hand, the impact of CYCLE on accruals earnings management is significantly positive, which is robust that companies with longer operating cycle have more incentives to manage accruals as they enjoy more accounting flexibility (Zang, 2012).

It is also possible to analyze the type of industries that manage earnings through real operations and accruals through industry dummies. For instance, chemicals industry (I4), automotive and components industry (I2), coal mining industry (I5), plantation industry (I10), property and real estate industry (I12), and transportation industry (I17) have been proven to significantly conduct real earnings management practices through reduction in cost of goods sold per unit sales and reduction in discretionary expenses. Roychowdhury (2006) explains that manufacturing companies (such as companies in the chemicals industry, automotive and components industry, coal mining industry, plantation industry, and transportation industry) are the ones that are most capable to produce more units than needed in order to reduce cost of goods sold per unit sold, therefore they have more incentives to manage earnings through real operations. On the other hand, companies that 
contribute to accruals earnings management practices are from chemicals industry (I4), coal mining industry (I5), electronics industry (I6), food and beverages industry (I7), metal and allied products industry (I8), property and real estate industry (I12), retail trade industry (I14), transportation industry (I17), and wholesale industry (I18). However, since there are many industries and data units that are dropped from the sample, it is important to note that other industries may have contributed to earnings management practices as well.

\section{CONCLUSION}

This research investigates the impact of financial distress on different earnings management approaches, namely real earnings management and accruals earnings management in Indonesian publicly listed companies within a period of ten years (20052014). Financial distress has been proven to have a significant positive relationship with the magnitude of real earnings management and a significant negative relationship with the magnitude of accruals earnings management. Therefore, the healthier the company, the bigger the magnitude of real earnings management conducted through managing production costs and discretionary expenses. On the other hand, the lower the financial health of the company, the bigger the magnitude of accruals earnings management conducted through managing discretionary component of accruals. The phenomena may be explained from the idea that the healthier the company, the more capable it is to deviate from optimal business operations in order to reach earnings target. However, as the company faces a more severe financial condition, the company loses its competitive advantage in the industry and thus unable to conduct real earnings management as much as before. Therefore, the company switches to accruals earnings management instead.

\section{REFERENCES}

Agrawal, K., \& Chatterjee, C. (2015). Earnings Management and Financial Distress: Evidence from India. Global Business Review, 16(5S), 140S-154S.

Allen, E. J., Larson, C. R., \& Sloan, R. G. (2013). Accrual Reversals, Earnings and Stock Returns. Journal of Accounting and Economics, 56(1), 113-129.

Altman, E. I. (1984). A Further Empirical Investigation of the Bankruptcy Cost Question. The Journal of Finance, 39(4), 1067-1089.

Altman, E. I., Hartzell, J., Heine, M. L., \& Peck, M. (1995). Emerging Market Corporate Bonds - A Scoring System. In Emerging Market Capital Flows (pp. 391-400). Springer US.

Anggraeni, S., \& Fadilah, N. S. (2015). Pengaruh Manipulasi Aktivitas Riil Melalui Arus Kas Kegiatan Operasi Terhadap Kinerja Pasar. Prosiding Penelitian SPeSIA.

Badertscher, B. A. (2011). Overvaluation and the Choice of Alternative Earnings Management Mechanisms. The Accounting Review, 86(5), 1491-1518.

Bartov, E., Gul, F. A., \& Tsui, J. S. L. (2001). Discretionary-accruals models and audit qualifications. Journal of Accounting \& Economics, 30, 421-552.

Beneish, M. D. (2001). Earnings management: A perspective. Managerial Finance, 27(12), 3-17.

Bisogno, M., \& De Luca, R. (2015). Financial Distress and Earnings Manipulation: Evidence from Italian SMEs. Journal of Accounting and Finance, 4(1), 42-51.

Campa, D., \& Camacho-Miñano, M.-M. (2015). The impact of SME's pre-bankruptcy financial distress on earnings management tools. International Review of Financial Analysis. 42, 222234. 
Charitou, A., Lambertides, N., \& Trigeorgis, L. (2007). Earnings Behaviour of Financially Distressed Firms: The Role of Institutional Ownership. Abacus, 43(3), 271-296.

Chieng, J. (2013). Verifying the Validity of Altman's Z" Score as a Predictor of Bank Failures in the Case of the Eurozone (Doctoral dissertation, Dublin, National College of Ireland).

Cohen, D. A., Dey, A., \& Lys, T. Z. (2008). Real and accrual-based earnings management in the pre-and post-Sarbanes-Oxley periods. The accounting review, 83(3), 757-787.

Dechow, P. M., \& Skinner, D. J. (2000). Earnings Management: Reconciling the View of Accounting Academics, Practitioners, and Regulators. Accounting Horizons, 14(2), 235-250.

Dechow, P. M., Sloan, R. G., \& Sweeney, A. P. (1995). Detecting Earnings Management. The Accounting Review, 70(2), 193-225.

Dechow, P. M., Sloan, R. G., \& Sweeney, A. P. (1996). Causes and Consequences of Earnings Maniuplation: An Analysis of Firms Subject to Enforcement Actions by the SEC. Contemporary, 13(1), 1-36.

Enomoto, M., Kimura, F., \& Yamaguchi, T. (2015). Acrual-based and Real Earnings Management: An International Comparison for Investor Protection. Journal of Contemporary Accounting \& Economics, 11(3), 183-198.

Fama, E. F., \& MacBeth, J. D. (1973). Risk, Return, and Equilibrium: Empirical Tests. The Journal of Political Economy, 81(3), 607-636.

Graham, J. R., Harvey, C. R., \& Rajgopal, S. (2005). The economic implications of corporate financial reporting. Journal of Accounting and Economics, 40(2005), 3-73. h

Gunny, K. (2005). What Are the Consequences of Real Earnings Management? Berkeley. Retrieved from http://w4.stern.nyu.edu/accounting/docs/speaker_papers/spring2005/Gunny_paper.pdf

International Accounting Standards Board (2010). Conceptual Framework for Financial Reporting 2010. London, UK: IFRS Foundation.

Iturriaga, F. J. L., \& Hoffmann, P. S. (2005). Earnings Management and Internal Mechanisms of Corporate Governance: Empirical Evidence from Chilean Firms. Corporate Ownership and Control, 3(1), 17-29.

Januarsi, Y., Badina, T., \& Febrianti, D. (2014). Leverage, Corporate Strategy and Earnings Management: Case of Indonesia. GSTF Journal on Business Review, 3(2), 54-59.

Joosten, C. (2012). Real earnings management and accrual-based earnings management as substitutes. Tilburg University Master Thesis. Retrieved from arno.uvt.nl/show.cgi?fid $=127248$

Kim, B. H., Lei, L., \& Pevzner, M. (2011). Debt Covenant Slack and Real Earnings Management. SSRN Working Paper Series. Retrieved from http://search.proquest.com/docview/815316704?accountid=26357

Kothari, S. P., Leone, A. J., \& Wasley, C. E. (2005). Performance matched discretionary accrual measures. Journal of Accounting and Economics, 39(1), 163-197.

Kothari, S. P., Mizik, N., \& Roychowdhury, S. (2016). Managing for the Moment: The Role of Earnings Management via Real Activities versus Accruals in SEO Valuation. The Accounting Review, 91(2), 559-586.

Lasdi, L. (2013). The Effect of Information Asymmetry of Earnings Management through Accrual and Real Activities during Global Financial Crisis. Journal of Economics, Business, and Accountancy Ventura, 16(August 2013), 325-338.

Leuz, C., Nanda, D., \& Wysocki, P. D. (2003). Earnings management and investor protection: an international comparison. Journal of Financial Economics, 69(3), 505-527.

Nagar, N., \& Sen, K. (2016). Earnings Management Strategies during Financial Distress. CORPORATE OWNERSHIP \& CONTROL, 774.

Nikoomaram, H., Banimahd, B., \& Shokri, A. (2012). An Empirical Analysis of Earnings Management Motives in Firms Listed on Tehran Stock Exchange. Journal of Basic and Applied Scientific Research, 2(10), 9990-9993.

Razzaque, R. M. R., Ali, M. J., \& Mather, P. R. (2015). Real earnings management in family firms: 
Evidence from an emerging economy. Pacific-Basin Finance Journal 22(3), 1-34.

Roychowdhury, S. (2006). Earnings management through real activities manipulation. Journal of Accounting and Economics, 42(3), 335-370.

Samarakoon, L. P., \& Hasan, T. (2003). Altman's Z-Score Models of Predicting Corporate Distress: Evidence from the Emerging Sri Lankan Stock Market. Journal of the Academy of Finance, (Fall 2003), 119-125.

Schipper, K. (1989). Commentary on earnings management. Accounting horizons, 3(4), 91-102.

Sloan, R. G. (1996). Do Stock Prices Fully Reflect Information in Accruals and Cash Flows about Future Earnings? The Accounting Review, 71(3), 289-315.

Soderstrom, N. S., \& Sun, K. J. (2007). IFRS Adoption and Accounting Quality: A Review. European Accounting Review, 16(4), 675-702.

Subramanyam, K. R. (1996). The pricing of discretionary accruals. Journal of Accounting and Economics, 22(1996), 249-281.

Tabassum, N., Kaleem, A., \& Nazir, M. S. (2015). Real Earnings Management and Future Performance. Global Business Review, 16(1), 21-34.

Tendeloo, B. van, \& Ann, V. (2005). Earnings management under German GAAP versus IFRS. European Accounting Review, 14(1), 155-180.

Whitaker, R. B. (1999). The Early Stages of Financial Distress. Journal of Economics and Finance, 23(2), 123-133.

Wruck, K. H. (1990). Financial distress, reorganization, and organizational efficiency. Journal of Financial Economics, 27(1990), 419-444.

Yaping, N. (2005). The Theoretical Framework of Earnings Management. Canadian Social Science, $1(3), 32-38$.

Yang, T.-H., Hsu, J., \& Yang, W.-B. (2015). Firm's motives behind SEOs, earnings management, and performance. International Review of Economics \& Finance, 2-24.

Zamri, N., Rahman, R. A., \& Isa, N. S. M. (2013). The Impact of Leverage on Real Earnings Management. Procedia Economics and Finance, 7(ICEBR 2013), 86-95.

Zang, A. Y. (2012). Evidence on the Trade-Off between Real Activities Manipulation and AccrualBased Earnings Management. The Accounting Review, 87(2), 675-703. 